\title{
INFLUENCE OF POTASSIUM ON THE GROWTH AND DEVELOPMENT OF FIBER IN EGYPTIAN COTTON
}

\author{
(Received: 7.11.2019) \\ By \\ Shimaa A. Shahat \\ Cotton Research Institute, Agricultural Research Center, Giza, Egypt.
}

\begin{abstract}
The present investigation was carried out to study the effect of potassium foliar application on cotton fiber length, rate of elongation, cellulose deposition, fiber quality properties and some yield traits. Giza 94 and Giza 95 LS Egyptian cotton varieties were used in pots experiment at the wire green house during 2017 and 2018 seasons. Potassium foliar treatments included four doses, namely control and (10,15 and $20 \mathrm{~g} / \mathrm{l})$, where each dose was divided into three equal parts; the first part was applied 80 days after planting (the beginning of flowering), the second was added after two weeks from the first part application (in the middle of fiber elongation stage), and the third part was added after two weeks from the second (in the middle of secondary wall thickening). The results indicated that the foliar application of $\mathrm{k}$ proved to have a great effect in improving and raising the productivity and fiber quality. $\mathrm{K}$ foliar application in the beginning and during flowering caused clear overlapping between fiber elongation and cellulose deposition (maturity) phases. Furthermore, boll weight, seed index, lint $\%$ and most of fiber properties were improved by $\mathrm{K}$ foliar treatments. $15 \mathrm{~g} / \mathrm{l}$ of $\mathrm{K}$ foliar application showed the longest and more mature fibers and the highest levels of the other fiber properties besides improving boll weight, lint and seed index.
\end{abstract}

Key word: Cotton- quality - Fiber development - Potassium - foliar application.

\section{INTRODUCTION}

Potassium is a mobile element inside the plant. It can easily move between plant organs. Potassium has an important role in a number of enzymes including those implicated with energy transfer,where plants require potassium for the production of high-energy phosphate molecules (ATP) produced in both photosynthesis and respiration. It is necessary for osmotic regulation and carbohydrates transfer. Furthermore, it affects the rate of transpiration and water uptake through regulating stomata opening. It is also involved in nitrogen metabolism and protein synthesis. Maintaining adequate plant $\mathrm{K}$ concentration can reduce the incidence of damping off diseases (Pettigrew, 2008). The amount of photosynthetic available for reproductive sinks is reduced when $\mathrm{K}$ is lower than normal because potassium has pronounced effects on carbohydrate partitioning by affecting either phloem export of photosynthess (sucrose) or source organs (Cakmak et al., 1994). Potassium could be added as soil application, it acts as an ion in the soil solution and its uptake is affected by competition with the other cations in that solution including $\mathrm{NH}_{4}^{+}, \mathrm{Na}^{+}, \mathrm{Mg}^{++}$and
$\mathrm{Ca}^{++}$. However, it could be applied as foliar potassium to cotton plants at square initiation, flower initiation and peak boll development. Potassium foliar application may allow correction of these deficiencies more quickly and efficiently than soil application, reflected rapidly and positively on cotton yield and fiber quality (Abaye, 1996; Howord et al. 2000). Moreover Pettigrew et al.(2000) and Muhammad et al. (2016)and (2017) reported that potassium $(\mathrm{K})$ is an essential nutrient for normal plant growth and development, in addition to playing an important role in fiber development. Therefore, its deficiency results in decreased cotton yield and quality. Dewdar,(2013) indicated that, soil application in addition to foliar spray of $2 \% \mathrm{~K}_{2} \mathrm{SO}_{4}$ at early and peak boll formation stages showed better levels of growth, yield traits and fiber quality measurements than potassium soil application only. Weir, (1998) and Rajendran et al. (2010) reported that, applying both potassium sources $\mathrm{K}_{2} \mathrm{SO}_{4}$ and $\mathrm{KNO}_{3}$ as foliar spray increased yield up to $75 \mathrm{~kg} / \mathrm{ha}$ and improved fiber quality. They added that the physiological role of potassium in fruit formation and ripening can be related to its 
role in the transportation of metabolism products from the leaves to the growing bolls. Increasing $\mathrm{K}$ concentration significantly increased boll weight leading to higher cotton yield. Ali and Armin (2016) and Mohammad et al. (2016) also, showed that, the amount of photosynthesis available for reproductive sinks reduced when $\mathrm{K}$ is lower than normal. Zhao et al. (2001) showed that, accumulation of sucrose in leaves of $\mathrm{K}$ deficient plants might be associated with reduced entry of sucrose into the transport pool or decreased phloem loading. $\mathrm{K}$ deficiencies during squaring also dramatically reduced leaf area and dry matter accumulation, besides affecting assimilate partitioning among plant tissues. Zahoor et al. (2017) indicated that foliar application of potassium at later stage of cotton growth had an important function for good fiber development. They added that adding $1.5 \%$ $\mathrm{K}_{2} \mathrm{O}$ enhanced the fiber quality of cotton compered with the other treatments; $0,1 \%$ and $2 \% \mathrm{~K}_{2} \mathrm{O}$. Zahoor et al. (2018) concluded that. $\mathrm{K}$ foliar application at the optimal level can decrease the extreme losses imported by the water stress in crop plants as well as efficiently enhances the yield-related parameters. Ruan et al. (2001) cleared that potassium plays an important role in fiber elongation and maturity development. Deficiency of this nutrient results in reduced yield (low maturity) and shorter fibers since $\mathrm{K}$ provides pressure inside the fiber cell walls necessary for fiber elongation and its role in transportation of photosynthesis products to the boll. Xi et al. (1989) reported that, since K is associated with the transport of sugars from leaves to bolls, it is likely implicated with secondary wall deposition in fibers, therefore, it is related to fiber strength and micronair value (maturity). Shanmugham and Bhat, (1991) Aladakatti et al. (2011)Found noticeable improvement in fiber length, uniformity ratio, fiber strength and maturity through foliar application of $\mathrm{K}$ at flowering. Oosterhuis, (2002) found that, limited supply of potassium during active fiber growth period may cause reduction in the turgor pressure of the fiber resulting in less cell elongation and shorter fibers at maturity. Andrew, (2001) mentioned that potassium deficiency can reduce fiber length even at moderate levels of yield loss due to the very sensitive nature of fiber quality to potassium levels in the boll. Eiaz et al. (2011) reported that the rate of potassium foliar spray showed significant effect on the number of bolls, boll weight, yield per plant and lint percentage besides, improved fiber length. Dewdar and Rady (2013) reported that, it is noticeable that adding NPK plus 2 times foliar spray of $2 \% \mathrm{~K}_{2} \mathrm{O}$ surpasses the other treatments in growth traits and fiber quality. Afnan et al.,(2015) indicated that, $\mathrm{K}$ foliar application can decrease the cost of potassium nutrients and enhance yield quality.

The main objectives of this investigation were to study:

- The effect of potassium foliar application on cotton fiber development (elongation, perimeter and cellulose deposition).

- The effect of potassium foliar application on yield traits and fiber quality measurements.

\section{MATERIAL AND METHODS}

A pot experiment was carried out in 2017 and 2018 seasons at the wire green house of Plant Physiology Department, Cotton Research Institute, Agricultural Research Center, Giza, Egypt. Two Egyptian cotton varieties namely; Giza 94 and Giza 95 (Gossypium barbadense L.) were used. Temperature during both seasons is shown in Table (1). Sowing dates were $10^{\text {th }}$ of May 2017 and $12^{\text {th }}$ of May 2018. 96 pots of 40 $\mathrm{cm}$ diameter were used in each season. Twelve pots for each treatment, each pot was filled with soil taken from the Agricultural Experimental Station Farm, CRI, ARC, Giza. Soil samples were taken randomly before sowing to determine the physicochemical properties; the results of soil analysis are recorded in Table (2). Irrigation was carried out regularly when needed using tap water. The cotton plants were thinned to two plants in each pot. Fertilization was conducted according to the recommended dose of $\mathrm{N}$ and $\mathrm{P}$ but without adding of $\mathrm{K}$. Pest control was conducted by using Tyleton $(1.2 \mathrm{~cm} / \mathrm{l})$ starting from the beginning of boll development and every 15 days for two times. Potassium foliar application treatments included four doses; 0, 10, 15 and 20g/l, each dose was divided into three equal parts; the first part was applied 80 days after planting (the beginning flowering), the second part of each dose was added after two weeks from the first part application (in the middle of fiber elongation stage), the third part was added after two weeks from the second one (in the middle of secondary wall thickening). During flowering, some flowers from the different plants were labeled in the day of an thesis to enable obtaining bolls of known age. Bolls of 10 ages, 5, 10, 15, 20, 25, $30,35,40$ and 45-48 days from flowering were used in this study. The selected bolls of each age 
Table (1): Degree of temperature in 2017 and 2018 seasons.

\begin{tabular}{|c|c|c|c|c|c|c|c|}
\hline & & \multicolumn{3}{|c|}{2017 season } & \multicolumn{3}{c|}{ 2018 season } \\
\hline Month & Period & \multicolumn{3}{|c|}{ Temperature $\left({ }^{\circ}\right.$ C) } & \multicolumn{3}{c|}{ Merature ${ }^{\circ}$ C) } \\
\hline & & Max. & Min. & Mean & Max. & Min. & Mean \\
\hline May & $1-10$ & 34.4 & 18.7 & 28.9 & 33.3 & 19.9 & 29.0 \\
\hline & $11-20$ & 34.5 & 19.8 & 29.2 & 34.3 & 19.8 & 28.7 \\
\hline & $21-30$ & 35.0 & 19.6 & 29.7 & 37.6 & 23.5 & 32.4 \\
\hline Average & & 34.6 & 19.4 & 29.3 & 35.1 & 21.1 & 30.0 \\
\hline June & $1-10$ & 37.1 & 21.9 & 30.6 & 35.7 & 21.9 & 30.5 \\
\hline & $11-20$ & 36.8 & 23.5 & 34.5 & 35.5 & 24.2 & 29.9 \\
\hline & $21-30$ & 36.2 & 29.5 & 31.7 & 37.2 & 34.2 & 32.4 \\
\hline Average & & 36.7 & 25.0 & 32.3 & 36.5 & 26.8 & 31.5 \\
\hline July & $1-10$ & 38.5 & 24.6 & 33.6 & 37.4 & 23.7 & 32.3 \\
\hline & $11-20$ & 39.2 & 24.6 & 34.4 & 37.9 & 24.6 & 32.2 \\
\hline & $21-30$ & 37.0 & 24.3 & 32.6 & 38.5 & 25.0 & 33.4 \\
\hline Average & & 38.2 & 24.5 & 33.5 & 37.9 & 24.4 & 32.6 \\
\hline August & $1-10$ & 37.7 & 24.8 & 33.5 & 37.9 & 25.4 & 32.7 \\
\hline & $11-20$ & 37.3 & 25.1 & 32.6 & 36.9 & 25.1 & 31.9 \\
\hline & $21-30$ & 36.4 & 23.8 & 31.5 & 36.6 & 24.9 & 31.7 \\
\hline Average & & 37.1 & 24.6 & 32.5 & 37.1 & 25.1 & 32.1 \\
\hline September & $1-10$ & 35.4 & 22.4 & 31.1 & 37.0 & 25.0 & 31.9 \\
\hline & $11-20$ & 36.1 & 22.8 & 31.3 & 35.1 & 23.4 & 30.7 \\
\hline & $21-30$ & 33.3 & 21.6 & 29.2 & 34.7 & 23.9 & 30.6 \\
\hline Average & & 34.9 & 22.3 & 30.5 & 35.6 & 24.1 & 31.1 \\
\hline & & & & & & & \\
\hline
\end{tabular}

were taken from the plant and transported directly to the Lab of Fiber Structural Properties, Cotton Fiber Res. Department, Cotton Res. Institute to measure fiber diameter, perimeter $(3.14 \mathrm{x}$ diameter) and following up the development of fiber elongation and cellulose deposition (maturity) under different ages. To follow up fiber elongation and its rate, 10 fibers were taken from each side of the clazal part of the seed and measured their length using especial ruler. The obtained length data average to represent fiber length of each boll age. Cellulose deposition was expressed as the degree of thickening, which was calculated according to the formula of Lord, (1981).

Degree of thickening $=\frac{\text { area of cellulose }}{\text { (circular cross section area })} \%$ By 50 days boll age, bolls were opened and the fibers were dried therefore, it was treated with $18 \%$ sodium hydroxide to be swollen again for measuring fiber perimeter and wall thickening using Image Analysis System. Boll weight in grams, seed index and lint percentage were determined. Micronair reading, maturity ratio,
Table (2): Physicochemical properties of experimental soil (Average of the two seasons)

\begin{tabular}{|c|c|}
\hline pH & 7.91 \\
\hline Electrical conductivity $(\mathrm{dS})$ & 1.52 \\
\hline Saturation percentage $\left(\mathrm{g} / \mathrm{cm}^{3}\right.$ & 53.0 \\
\hline \multicolumn{2}{|l|}{ Soluble anions (meq/1): } \\
\hline $\mathrm{CO}_{3}^{2-}$ & -- \\
\hline $\mathrm{HCO}_{3}$ & 3.58 \\
\hline $\mathrm{Cl}$ & 5.30 \\
\hline $\mathrm{SO}_{4}$ & 6.35 \\
\hline \multicolumn{2}{|c|}{ Soluble cations (meq/1): } \\
\hline $\mathrm{Ca}^{2+}$ & 5.96 \\
\hline $\mathrm{Mg}^{2+}$ & 2.94 \\
\hline $\mathrm{Na}^{+}$ & 5.96 \\
\hline $\mathrm{K}^{+}$ & 0.37 \\
\hline \multicolumn{2}{|c|}{ Available minerals (mg/Kg soil) } \\
\hline $\mathrm{N}$ & 44.63 \\
\hline $\mathrm{P}$ & 9.19 \\
\hline $\mathrm{K}$ & 478.8 \\
\hline $\mathrm{Cu}$ & 8.08 \\
\hline $\mathrm{Fe}$ & 34.70 \\
\hline $\mathrm{Mn}$ & 8.85 \\
\hline $\mathrm{Zn}$ & 10.68 \\
\hline
\end{tabular}


fiber length, uniformity index and fiber strength were measured on HVI system according to ASTM-D-5867-05(2005). The obtained data were subjected to analysis of variance in a completely randomized design with three replicates. LSD 5\% test was employed to compare the different means of each studied character. The analysis of variance and LSD were carried out according to Snedecor and Cochoran (1986). It is worthy to report that applying parttelet test was not significant indicating the homogeneity of the obtained data; therefore, the data of each character was subjected to combine analysis of variance.

\section{RESULTS AND DISCUSSION}

Cotton fiber development could be noticed in two stages, the first one is the elongation stage which starts in the first day of flowering when cotton fibers begin to initiate from the ovule's outer layer cells, then start lengthening for a period of about 25-30 days, as a thin cell wall of carbohydrate polymers deposited in a form allowing the fiber to elongate. The second stage is the cellulose deposition stage, which starts after the elongation stage when cellulose fibrils start depositing inside the primary wall forming the secondary wall layers. This stage continues 20 to 30 days after the elongation stage; however, an overlapping could be noticed between the two stages.

Aiming to study the effect of potassium foliar application on cotton fiber development (elongation, perimeter and cellulose deposition) it was necessary to follow up fiber elongation and cellulose deposition of the different boll ages from (5 days) of boll age to final age just before boll opening (45-48 day).

\subsection{Effect of potassium foliar application on cotton fiber length and elongation rate:}

The results in Table (3), Table (4) and illustrated in Fig. (1) indicated that potassium foliar application increased significantly fiber elongation rate and the final fiber length in the two cotton varieties in both seasons, furthermore, the differences in fiber length between potassium treatments, boll ages, growing seasons and their interactions were statistically significant.

Regarding Giza 94, the combined analysis of the two seasons revealed that potassium treatments; 10,15 and $20 \mathrm{~g} / 1$ recorded fiber length $9.33,10.20$ and $9.38 \mathrm{~mm}$, respectively, in 5 days boll age compared to $8.88 \mathrm{~mm}$ for the control, while recorded in 30 day boll age 36.14, 36.84 and $36.68 \mathrm{~mm}$, respectively, compared to 34.70 $\mathrm{mm}$ in the control, and recorded in the final boll age $36.74,37.79$ and $37.40 \mathrm{~mm}$ for the same concentrations respectively compared to $35.85 \mathrm{~mm}$ for the control. Fiber elongation rate and the final fiber length of Giza 95 showed the same trend of Giza 94, to be 8.36, 8.94 and 8.53 $\mathrm{mm}$ compared to $7.62 \mathrm{~mm}$ for the control in 5 days boll age, while being $31.80,32.41$ and $32.09 \mathrm{~mm}$ in 30 day boll age compared to 30.61 $\mathrm{mm}$ In the control and being 32.38, 33.36 and $32.48 \mathrm{~mm}$ in the final age compared to $30.90 \mathrm{~mm}$ in the control. Potassium treatments showed the same trend in the two seasons regarding its effect on fiber elongation rate and the final fiber length. $15 \mathrm{~g} / 1$ potassium treatment showed the highest fiber elongation rate and the final fiber length compared to the other $\mathrm{K}$ treatments in both cotton varieties.

There was an overlapping between elongation stage and cellulose deposition stage, elongation stage extent to the 40 days age. While, the cellulose deposition started from 20 day age in potassium treatments and 25 day age for the control. The difference between seasons, concentrations, ages and their interaction were significant. The results indicated that the second season showed significant increase in fiber elongation rates during the different boll ages compared to the first season, which may be due partially to the increase of day temperature and humidity during the main elongation time in July and August (Table 1). Potassium role in fiber elongation rate is related to the role of $\mathrm{K}$ in the maintenance of osmotic potential to generate the turgor pressure necessary for fiber elongation, besides increasing IAA, GA3 content in boll fibers, that led to increase fiber elongation and elongation rate in all boll ages. Moreover $\mathrm{K}$ application can make the plant more tolerant to water stress that increasing fiber elongation Chen et al. (2017, Howard et al. 2000; Abaya, 1996; Oosterhuis, (2002,) came to similar conclusion.

\subsection{Effect of potassium foliar application on the secondary wall cellulose deposition:}

The results in Tables $(5,6)$ and illustrated in Fig. (2) indicated that, foliar application of potassium increased significantly cellulose deposition rate and the final deposition of cellulose in the fibers of the two cotton varieties in both seasons, furthermore, the differences in cellulose deposition between potassium treatments, boll ages, growing seasons and their interactions were statistically significant. 
Table (3): Effect of potassium foliar application treatments on fiber length and elongation rate of Giza 94 variety in 2017 and 2018 season.

\begin{tabular}{|c|c|c|c|c|c|c|c|c|c|c|}
\hline \multirow{3}{*}{ Seasons $(\mathbf{S})$} & \multirow{3}{*}{$\begin{array}{c}\text { Potassium } \\
\text { Concentration } \\
\text { (C) }\end{array}$} & \multicolumn{9}{|c|}{ Fiber length and elongation rate(mm) } \\
\hline & & \multicolumn{9}{|c|}{ Boll age $(A)$} \\
\hline & & $\begin{array}{l}5 \\
\text { days }\end{array}$ & $\begin{array}{c}10 \\
\text { day }\end{array}$ & $\begin{array}{c}15 \\
\text { days }\end{array}$ & $\begin{array}{c}20 \\
\text { days }\end{array}$ & $\begin{array}{c}25 \\
\text { days }\end{array}$ & $\begin{array}{c}30 \\
\text { days }\end{array}$ & $\begin{array}{c}35 \\
\text { days }\end{array}$ & $\begin{array}{c}40 \\
\text { days }\end{array}$ & $\begin{array}{c}45-48 \\
\text { days }\end{array}$ \\
\hline \multirow{5}{*}{2017} & 0 k (control) & 8.83 & 20.20 & 30.26 & 32.27 & 33.14 & 34.20 & 34.80 & 35.58 & 35.70 \\
\hline & $10 \mathrm{~g} / \mathrm{L}$ & 9.20 & 21.52 & 32.33 & 34.48 & 34.57 & 35.64 & 35.80 & 36.43 & 36.63 \\
\hline & $15 \mathrm{~g} / \mathrm{L}$ & $\mathbf{1 0 . 5 3}$ & 22.55 & 33.31 & 35.33 & 35.53 & 36.34 & 36.93 & 37.48 & 37.66 \\
\hline & $20 \mathrm{~g} / \mathrm{L}$ & 9.34 & 21.45 & 32.50 & 34.70 & 35.20 & 36.18 & 36.51 & 37.03 & 37.32 \\
\hline & MEAN & 9.48 & 21.43 & 32.10 & 34.19 & 34.61 & 35.59 & 36.01 & 36.63 & 36.83 \\
\hline \multirow{5}{*}{2018} & 0 k (control) & 8.92 & 22.30 & 31.22 & 33.17 & 34.51 & 35.20 & 35.76 & 35.98 & 36.00 \\
\hline & $10 \mathrm{~g} / \mathrm{L}$ & 9.45 & 23.62 & 33.06 & 35.38 & 36.17 & 36.64 & 36.66 & 36.83 & 36.85 \\
\hline & $15 \mathrm{~g} / \mathrm{L}$ & 9.86 & 24.65 & 34.51 & 36.23 & 36.97 & 37.34 & 37.58 & 37.88 & 37.92 \\
\hline & $20 \mathrm{~g} / \mathrm{L}$ & 9.42 & 23.55 & 32.97 & 35.60 & 36.53 & 37.18 & 37.27 & 37.43 & 37.47 \\
\hline & MEAN & 9.41 & 23.53 & 32.94 & 35.09 & 36.04 & 36.59 & 36.82 & 37.03 & 37.06 \\
\hline \multirow{5}{*}{ Combined } & 0 k (control) & 8.88 & 21.25 & 30.74 & 32.72 & 33.83 & 34.70 & 35.28 & 35.78 & 35.85 \\
\hline & $10 \mathrm{~g} / \mathrm{L}$ & 9.33 & 22.57 & 32.70 & 34.93 & 35.37 & 36.14 & 36.23 & 36.63 & 36.74 \\
\hline & $15 \mathrm{~g} / \mathrm{L}$ & 10.20 & 23.60 & 33.91 & 35.78 & 36.25 & 36.84 & 37.26 & 37.68 & 37.79 \\
\hline & $20 \mathrm{~g} / \mathrm{L}$ & 9.38 & 22.50 & 32.74 & 35.15 & 35.87 & 36.68 & 36.89 & 37.23 & 37.40 \\
\hline & General mean & 9.45 & 22.48 & 32.52 & 34.64 & 35.33 & 36.09 & 36.42 & 36.83 & 36.95 \\
\hline
\end{tabular}

LSD 0.5 :-
$(\mathrm{S})$ :
0.15
(A):
(C):
0.21
( S X A ): 0.43
( S X C): 0.28
(A X C ): 0.61
( S X A X C): 0.86

Table (4): Effect of potassium foliar application treatments on fiber length and elongation rate of Giza 95 variety in 2017 and 2018 seasons.

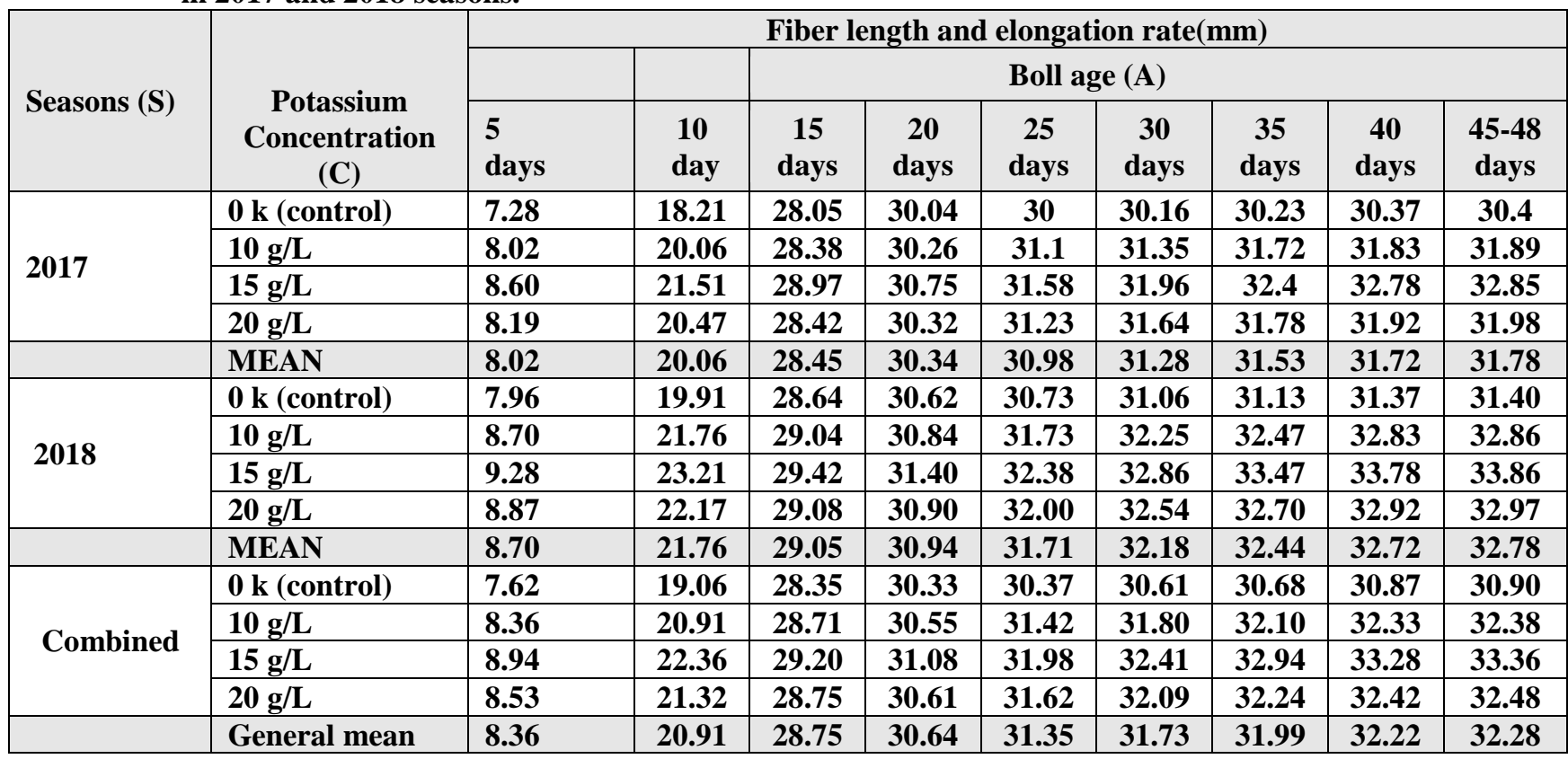

LSD 0.5 :-
( S ): $\quad 0.13$
(A): $\quad 0.27$
(C):
0.18
( S X A ): 0.38
( S X C): 0.25
( A X C ): 0.53
(S X A X C): 0.75 

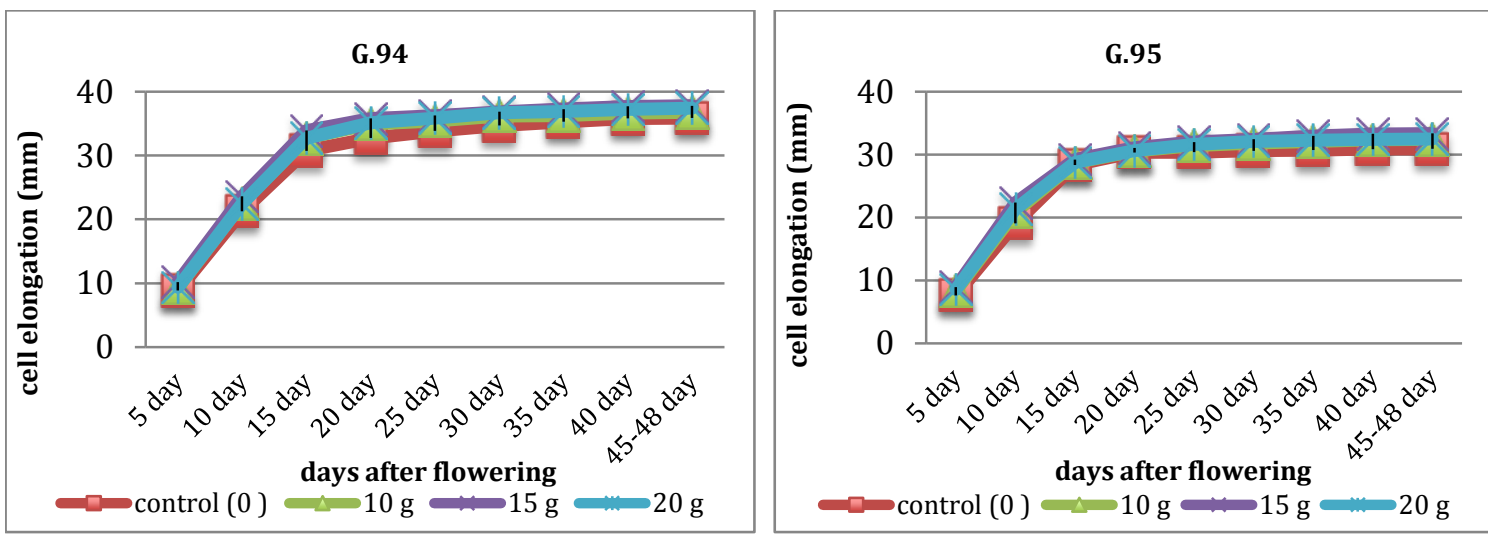

Fig (1): Effect of potassium foliar application treatments on cell elongation stages in both varieties.

Table (5): Effect of potassium foliar application treatments on degree of thickening and its rate of Giza 94 variety in 2017 and 2018 seasons.

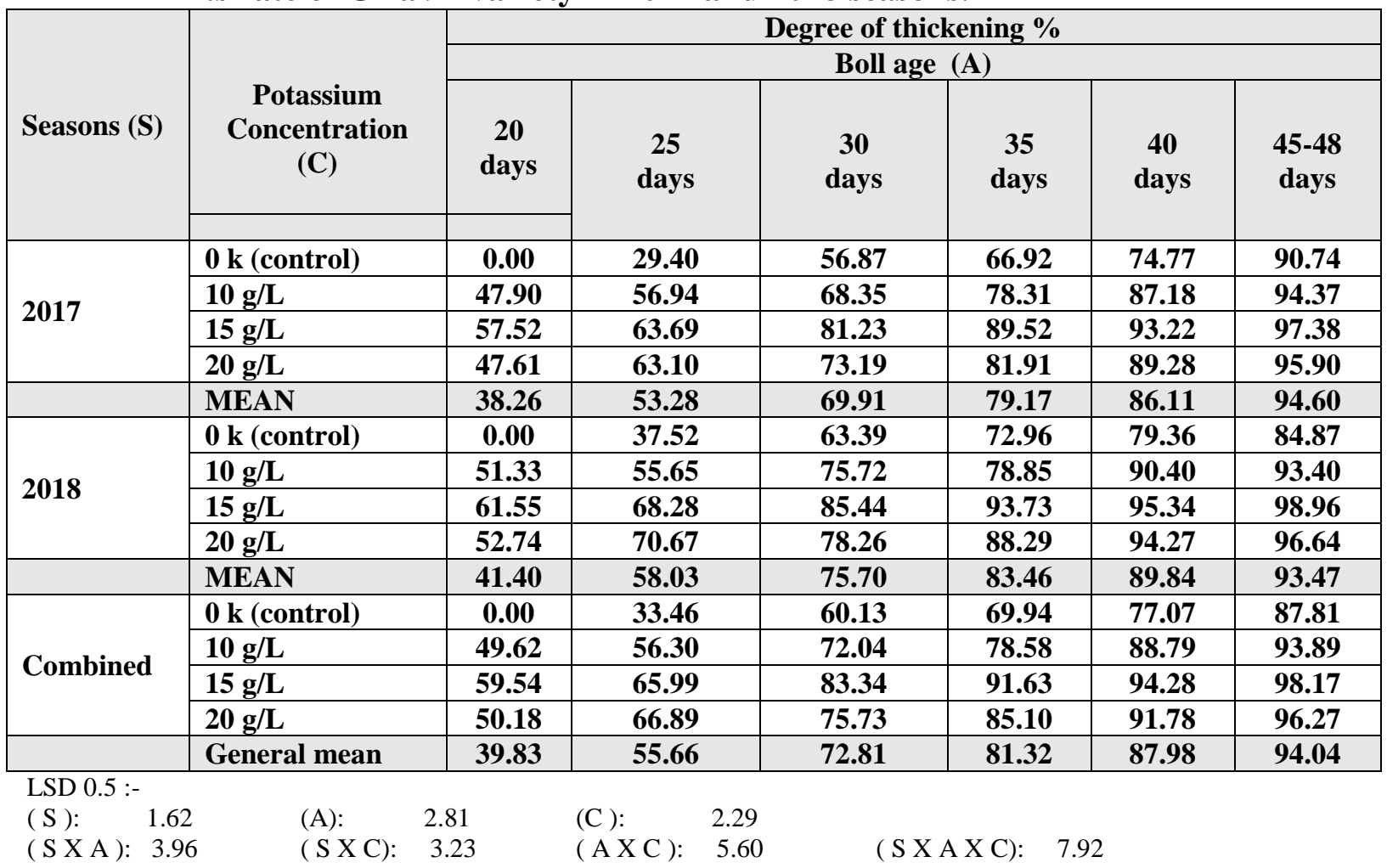

Cellulose deposition of the different boll ages starting from 20 days to the final age just before boll opening (45-48 day). was expressed as a degree of thickening.

Regarding Giza 94, the combined analysis of the two seasons revealed that, potassium treatments; 10,15 and $20 \mathrm{~g} / 1$ recorded 49.62 , 59.54 and $50.18 \%$ for the degree of thickening respectively in 20 days boll age while the control did not show any cellulose deposition in this age. At 35 days boll age the three potassium treatments recorded $78.58,91.63$ and $85.10 \%$ respectively compared to $69.94 \%$ in the control, and recorded in the final boll age 93.89, 98.17 and $96.27 \%$ compared to $87.81 \%$ for the control. Cellulose deposition rate and the final deposition of cellulose of Giza 95 showed the same trend of Giza 94 in both seasons, to be 64.86, 65.17 and $66.49 \%$ for $\mathrm{K}$ treatments, respectively, in 20 days boll age while the control did not show any cellulose deposition in this age, while being $87.26,96.66$ and $89.22 \%$ in 35 days boll age compared to 73.16. In the control it was $96.68,99.34$ and $97.58 \%$ in the final age compared to $81.16 \%$ in the control. 
Table (6): Effect of potassium foliar application treatments on degree of thickening and its rate of Giza 95 variety in 2017 and 2018 seasons.

\begin{tabular}{|c|c|c|c|c|c|c|c|}
\hline \multirow{3}{*}{ Seasons (S) } & \multirow{3}{*}{$\begin{array}{c}\text { Potassium } \\
\text { concentration } \\
\text { (C) }\end{array}$} & \multicolumn{6}{|c|}{ Degree of thickening \% } \\
\hline & & \multicolumn{6}{|c|}{ Boll age $(\mathrm{A})$} \\
\hline & & $\begin{array}{c}20 \\
\text { days }\end{array}$ & $\begin{array}{c}25 \\
\text { days }\end{array}$ & $\begin{array}{c}30 \\
\text { days }\end{array}$ & $\begin{array}{c}35 \\
\text { days }\end{array}$ & $\begin{array}{c}40 \\
\text { days }\end{array}$ & $\begin{array}{l}45-48 \\
\text { days }\end{array}$ \\
\hline \multirow{5}{*}{2017} & $0 \mathrm{k}$ (control) & 0.00 & 57.96 & 64.15 & 73.82 & 74.38 & 80.1 \\
\hline & $10 \mathrm{~g} / \mathrm{L}$ & 64.58 & 68.34 & 76.07 & 83.95 & 90.3 & 97.29 \\
\hline & $15 \mathrm{~g} / \mathrm{L}$ & 62.18 & 77.48 & $\mathbf{9 3 . 2 2}$ & 96.64 & 99.08 & 99.15 \\
\hline & $20 \mathrm{~g} / \mathrm{L}$ & 65.85 & 71.16 & 81.29 & 87.52 & 91.71 & 97.89 \\
\hline & MEAN & 48.15 & 68.73 & 78.68 & 85.48 & 88.87 & 93.6 \\
\hline \multirow{4}{*}{2018} & $0 \mathrm{k}$ (control) & 0.00 & 55.77 & $\mathbf{6 9 . 3 4}$ & 72.49 & 77.42 & 82.22 \\
\hline & $10 \mathrm{~g} / \mathrm{L}$ & 65.13 & 73.73 & 86.79 & 90.56 & 92.39 & 96.06 \\
\hline & $15 \mathrm{~g} / \mathrm{L}$ & 68.16 & 77.05 & 91.99 & 96.67 & 98.72 & 99.53 \\
\hline & $20 \mathrm{~g} / \mathrm{L}$ & 67.12 & 75.09 & 87.67 & 90.92 & 93.46 & 97.27 \\
\hline & MEAN & 50.1 & 70.41 & 83.95 & 87.66 & 90.49 & 93.77 \\
\hline \multirow{5}{*}{ Combined } & $0 \mathrm{k}$ (control) & 0.00 & 56.87 & 66.75 & 73.16 & 75.90 & 81.16 \\
\hline & $10 \mathrm{~g} / \mathrm{L}$ & 64.86 & 71.04 & 81.43 & 87.26 & 91.35 & 96.68 \\
\hline & $15 \mathrm{~g} / \mathrm{L}$ & 65.17 & 77.27 & 92.61 & 96.66 & 98.90 & 99.34 \\
\hline & $20 \mathrm{~g} / \mathrm{L}$ & 66.49 & 73.13 & 84.48 & 89.22 & 92.59 & 97.58 \\
\hline & General mean & 49.13 & 69.57 & 81.32 & 86.57 & 89.68 & 93.69 \\
\hline \multicolumn{8}{|c|}{$\begin{array}{ll}\text { LSD 0.5 :- } \\
\text { (S ): } & 1.36 \\
\text { ( S X A ): } & 3.32\end{array}$} \\
\hline
\end{tabular}
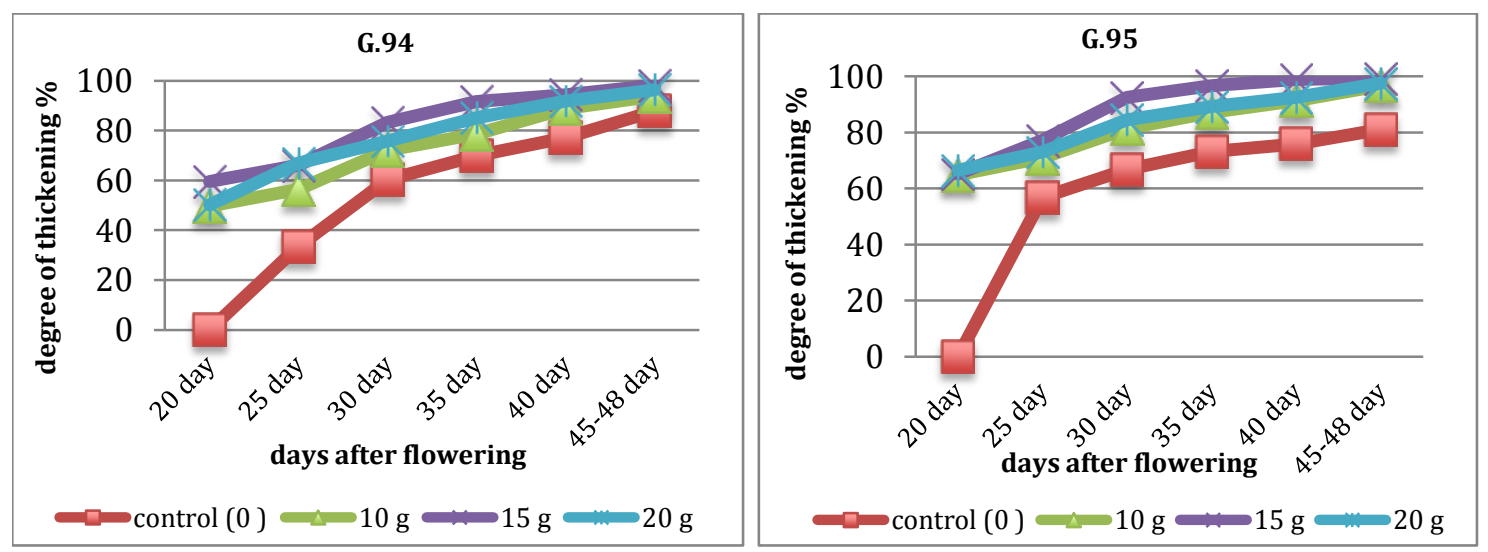

Fig (2): Effect of potassium foliar application treatments on degree of thickening stages in both varieties

potassium treatments showed the same trend in the two seasons regarding its effect on fiber elongation rate and the final fiber length. It is clear from the obtained results that all the potassium foliar application treatments increased significantly the rate of cellulose deposition and the final degree of thickening (fiber maturity). This is true since $\mathrm{k}$ is associated with the transport of sugars; it is likely implicated with secondary wall deposition in fibers and, therefore, related to fiber strength and micronaire. Moreover, $15 \mathrm{~g} / \mathrm{L}$ potassium treatment showed the highest degree of thickening rate and the final cellulose deposition compared to the other $\mathrm{K}$ treatments. Ruan et al. (2001) Oosterhuis, (2002) Xi et al.( 1989) came to similar conclusions.

\subsection{Effect of potassium foliar application on cotton fiber perimeter (green boll data):}

The effect of seasons, potassium treatments and most of the interactions on fiber perimeter were not statistically significant except for the effect of boll age and the second order interactions which were significant. The results in Tables (7 and 8 ) and illustrated in Fig. (3) cleared that, the fiber perimeter 
Table (7): Effect of potassium foliar application treatments on fiber perimeter of G.94 variety in 2017 and 2018 seasons.

\begin{tabular}{|c|c|c|c|c|c|c|c|c|c|c|c|}
\hline \multirow[b]{3}{*}{$\begin{array}{c}\text { Seasons } \\
\text { (S) }\end{array}$} & \multirow[b]{3}{*}{$\begin{array}{c}\text { Potassium } \\
\text { Concentration } \\
\text { (C) }\end{array}$} & \multicolumn{10}{|c|}{ Perimeter $(\mu)$} \\
\hline & & \multicolumn{10}{|c|}{ Boll age (A) } \\
\hline & & $\begin{array}{l}5 \\
\text { days }\end{array}$ & $\begin{array}{l}10 \\
\text { days }\end{array}$ & $\begin{array}{l}15 \\
\text { days }\end{array}$ & $\begin{array}{l}20 \\
\text { days }\end{array}$ & $\begin{array}{l}25 \\
\text { days }\end{array}$ & $\begin{array}{l}30 \\
\text { days }\end{array}$ & $\begin{array}{l}35 \\
\text { days }\end{array}$ & $\begin{array}{l}40 \\
\text { days }\end{array}$ & $\begin{array}{l}45-48 \\
\text { days }\end{array}$ & $\begin{array}{l}\text { Dry } \\
\text { fiber }\end{array}$ \\
\hline \multirow{5}{*}{2017} & 0 k (control) & 39.77 & 41.86 & 44.27 & 45.59 & 47.31 & 48.91 & 49.86 & 50.97 & 51.33 & 48.54 \\
\hline & $10 \mathrm{~g} / \mathrm{L}$ & 39.98 & 41.92 & 44.17 & 45.90 & 47.31 & 48.86 & 49.27 & 50.87 & 51.18 & 48.55 \\
\hline & $15 \mathrm{~g} / \mathrm{L}$ & 39.88 & 41.79 & 44.07 & 45.62 & 47.30 & 48.80 & 49.40 & 50.66 & 50.93 & 48.43 \\
\hline & $20 \mathrm{~g} / \mathrm{L}$ & 40.06 & 41.94 & 44.30 & 45.71 & 47.25 & 48.88 & 49.54 & 51.078 & 51.23 & 48.50 \\
\hline & MEAN & 39.92 & 41.88 & 44.20 & 45.71 & 47.29 & 48.86 & 49.63 & 50.89 & 51.17 & 48.51 \\
\hline \multirow{5}{*}{2018} & 0 k (control) & 39.98 & 42.23 & 44.07 & 45.55 & 47.46 & 48.71 & 49.50 & 50.98 & 51.39 & 48.53 \\
\hline & $10 \mathrm{~g} / \mathrm{L}$ & 39.88 & 42.23 & 43.96 & 45.55 & 47.25 & 48.62 & 49.23 & 50.87 & 51.21 & 48.49 \\
\hline & $15 \mathrm{~g} / \mathrm{L}$ & 40.04 & 42.22 & 43.98 & 45.40 & 47.21 & 48.68 & 49.15 & 50.91 & 51.17 & 48.47 \\
\hline & $20 \mathrm{~g} / \mathrm{L}$ & 39.87 & 42.13 & 43.96 & 45.61 & 47.31 & 48.75 & 49.27 & 51.06 & 51.21 & 48.45 \\
\hline & MEAN & 39.94 & 42.20 & 43.99 & 45.53 & 47.30 & 48.69 & 49.29 & 50.95 & 51.25 & 48.49 \\
\hline \multirow{5}{*}{ Combined } & 0 k (control) & 39.88 & 42.04 & 44.17 & 45.57 & 47.38 & 48.81 & 49.68 & 50.98 & 51.36 & 48.54 \\
\hline & $10 \mathrm{~g} / \mathrm{L}$ & 39.93 & 42.08 & 44.06 & 45.72 & 47.28 & 48.74 & 49.47 & 50.87 & 51.20 & 48.52 \\
\hline & $15 \mathrm{~g} / \mathrm{L}$ & 39.96 & 42.01 & 44.02 & 45.51 & 47.25 & 48.74 & 49.28 & 50.78 & 51.05 & 48.45 \\
\hline & $20 \mathrm{~g} / \mathrm{L}$ & 39.96 & 42.03 & 44.13 & 45.66 & 47.28 & 48.82 & 49.40 & 51.07 & 51.22 & 48.48 \\
\hline & General mean & 39.93 & 42.04 & 44.10 & 45.62 & 47.30 & 48.78 & 49.46 & 50.92 & 51.21 & 48.50 \\
\hline
\end{tabular}

LSD 0.5 :-

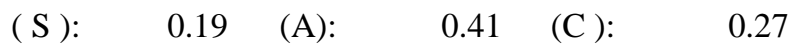

( S X A ): $0.58 \quad$ ( S X C): $0.38 \quad$ (A X C ): $0.82 \quad$ ( S X A X C): 1.15

Table (8): Effect of potassium foliar application treatments on fiber perimeter of G.95 variety in 2017 and 2018 seasons.

\begin{tabular}{|c|c|c|c|c|c|c|c|c|c|c|c|}
\hline \multirow{3}{*}{$\begin{array}{c}\text { Seasons } \\
\text { (S) }\end{array}$} & \multirow{3}{*}{$\begin{array}{c}\text { Potassium } \\
\text { Concentration } \\
\text { (C) }\end{array}$} & \multicolumn{10}{|c|}{ Perimeter $(\mu)$} \\
\hline & & \multicolumn{10}{|c|}{ Boll age $(\mathrm{A})$} \\
\hline & & $\begin{array}{l}5 \\
\text { days }\end{array}$ & $\begin{array}{l}10 \\
\text { days }\end{array}$ & $\begin{array}{l}15 \\
\text { days }\end{array}$ & $\begin{array}{l}20 \\
\text { days }\end{array}$ & $\begin{array}{l}25 \\
\text { days }\end{array}$ & $\begin{array}{l}30 \\
\text { days }\end{array}$ & $\begin{array}{l}35 \\
\text { days }\end{array}$ & $\begin{array}{l}40 \\
\text { days }\end{array}$ & $\begin{array}{l}45-48 \\
\text { days }\end{array}$ & $\begin{array}{l}\text { Dry } \\
\text { Fiber }\end{array}$ \\
\hline & 0 k (control) & 44.05 & 45.90 & 47.45 & 49.07 & 50.61 & 52.64 & 53.58 & 55.53 & 57.44 & 52.00 \\
\hline & $10 \mathrm{~g} / \mathrm{L}$ & 43.99 & 45.88 & 47.58 & 48.86 & 50.69 & 52.53 & 53.79 & 55.55 & 57.24 & 51.98 \\
\hline & $15 \mathrm{~g} / \mathrm{L}$ & 43.97 & 45.93 & 47.49 & 49.04 & 50.64 & 52.33 & 53.58 & 55.48 & 57.20 & 51.98 \\
\hline & $20 \mathrm{~g} / \mathrm{L}$ & 44.05 & 45.80 & 47.40 & 48.81 & 50.74 & 52.53 & 53.83 & 55.59 & 57.15 & 52.04 \\
\hline & MEAN & 44.02 & 45.88 & 47.48 & 48.94 & 50.67 & 52.51 & 53.69 & 55.54 & 57.26 & 52.00 \\
\hline \multirow{4}{*}{2018} & 0 k (control) & 44.17 & 45.68 & 47.31 & 49.29 & 50.69 & 52.81 & 53.80 & 55.72 & 57.19 & 51.87 \\
\hline & $10 \mathrm{~g} / \mathrm{L}$ & 44.26 & 45.53 & 47.32 & 49.22 & 50.67 & 52.91 & 53.61 & 55.59 & 57.20 & 52.10 \\
\hline & $15 \mathrm{~g} / \mathrm{L}$ & 44.16 & 45.56 & 47.33 & 49.25 & 50.63 & 52.76 & 53.57 & 55.60 & 57.04 & 51.92 \\
\hline & $20 \mathrm{~g} / \mathrm{L}$ & 44.12 & 45.70 & 47.42 & 49.32 & 50.56 & 52.85 & 53.66 & 55.64 & 57.29 & 52.13 \\
\hline & MEAN & 44.18 & 45.62 & 47.35 & 49.27 & 50.64 & 52.83 & 53.66 & 55.64 & 57.18 & 52.01 \\
\hline \multirow{5}{*}{ Combined } & 0 k (control) & 44.11 & 45.79 & 47.38 & 49.18 & 50.65 & 52.73 & 53.69 & 55.63 & 57.32 & 52.01 \\
\hline & $10 \mathrm{~g} / \mathrm{L}$ & 44.13 & 45.71 & 47.45 & 49.04 & 50.68 & 52.72 & 53.70 & 55.57 & 57.22 & 51.99 \\
\hline & $15 \mathrm{~g} / \mathrm{L}$ & 44.07 & 45.75 & 47.41 & 49.15 & 50.64 & 52.55 & 53.58 & 55.54 & 57.12 & 51.89 \\
\hline & $20 \mathrm{~g} / \mathrm{L}$ & 44.09 & 45.75 & 47.41 & 49.07 & 50.65 & 52.69 & 53.75 & 55.62 & 57.22 & 52.05 \\
\hline & General mean & 44.10 & 45.75 & 47.42 & 49.11 & 50.66 & 52.67 & 53.68 & 55.59 & 57.22 & 52.00 \\
\hline
\end{tabular}

LSD 0.5 :-
$(\mathrm{S})$ :
0.13
(A):
0.27
(C):
0.18
( S X A ): 0.37
( S X C): 0.25
(AXC): 0.54
(S X A X C): 0.76 

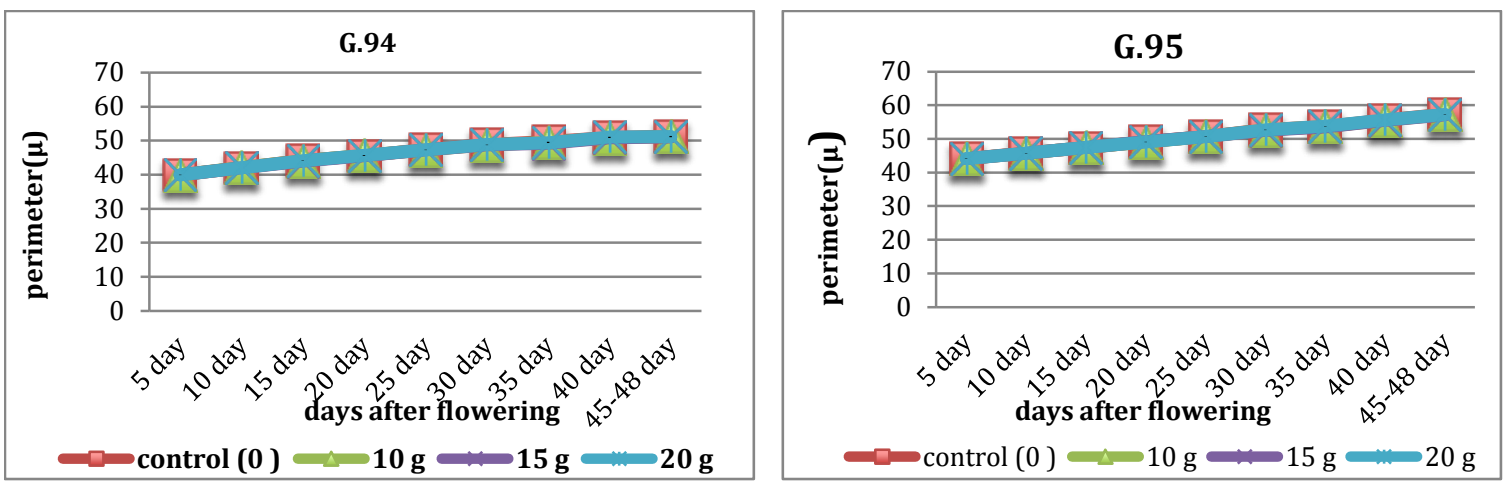

\section{Fig (3): Effect of potassium foliar application treatments on perimeter in both seasons for both varieties.}

increased as the fiber became older in both cotton varieties. However, G.95 proved to be coarser than G.94, and showed higher perimeter values along the different boll ages. Fiber perimeter is a varietal trait controlled mainly by genetics. Combined data of the two seasons revealed that fiber perimeter of G.94 ranged from $39.93 \mu$ at 5 days, $48.78 \mu$ at 30 days and $51.21 \mu$ at final boll age before opening. Dry fiber perimeter of G.94 averaged $(48.50 \mu)$ while, G.95 perimeter ranged from $(44.10 \mu$ at 5 day, $52.67 \mu$ at 30 day and $57.22 \mu$ at final boll age before opening. Dry fiber perimeter of G.95 averaged $(52.0 \mu)$. Fiber perimeter of the two varieties showed in 2018 the same trend of 2017 with no statistical difference between the two seasons. It is worthy to report that fiber intrinsic fineness (perimeter) is a varietal trait controlled mainly by genetics and the effect of environment and agronomic practices is of low magnitude. Younis,(2010) and Sief, et al. (2016) came to similar conclusions.

\section{4. effect of potassium foliar application on some yield and fiber quality traits:}

The results in Tables (9 and 10) indicated that potassium foliar application increased significantly yield traits (boll weight, seed index and lint $\%$ ) and fiber quality (micronaire value, maturity ratio, uniformity index and fiber strength) compared to the control in the two varieties along the two seasons. However, $15 \mathrm{~g} / 1$ of $\mathrm{K}$ treatment exhibited the highest level of the mentioned traits in both seasons for the two varieties.

Concerning boll weight of Giza 94, the combined analysis of the two seasons revealed that potassium treatments; 10,15 and $20 \mathrm{~g} / 1$ recorded 3.28, 3.44 and $3.28 \mathrm{~g}$ compared to 3.07 $\mathrm{g}$ in the control. Boll weight of Giza 95 showed the same trend of Giza 94, to be 3.20, 3.34 and $3.23 \mathrm{~g}$ compared to $2.99 \mathrm{~g}$ in the control.

As for seed index, the different $\mathrm{K}$ treatments recorded in Giza 94 11.06, 12.00 and $11.13 \mathrm{~g}$ respectively, compared to $10.74 \mathrm{~g}$ in the control. K treatments showed the same trend in Giza 95 to be $10.33,11.22$ and $10.53 \mathrm{~g}$ compared to $10.05 \mathrm{~g}$ in the control. Lint percentage showed the same trend of boll weight and seed index in both varieties during the two seasons. The results cleared that $15 \mathrm{~g} / \mathrm{l}$ of $\mathrm{K}$ treatment exhibited the best values of yield traits.

It could be concluded that foliar applications of potassium significantly improved the values of the studied yield traits. This may be due to the favorable effects of $\mathrm{K}$ on nutrient uptake, photosynthetic activity and improving its mobilization, which directly influences all of them Afinan et al. (2015), Pettigrew, (20000 Weir, (19980, Donald and Owen (1998), Cakmak et al. (1994) found similar results.

Regarding fiber quality, the results showed noticeable and statistically significant effects of $\mathrm{K}$ treatments, seasons and their interactions on fiber quality properties in both varieties compared with the control. The highest levels of fiber quality were obtained from $15 \mathrm{~g} / \mathrm{K}$ treatment.

Regarding micronaire value of Giza 94, the combined data revealed that potassium treatments; 10,15 and $20 \mathrm{~g} / 1$ recorded 3.97 , 4.06 and 3.85 compared to 3.97 in the control, and recorded in Giza 95: 4.88, 5.10 and 4.89 compared to 4.53 in the control. Maturity ratio showed the same trend of micronaire value in the two varieties along the two seasons.

Concerning fiber length of Giza 94, the obtained data indicated that potassium treatments; 10, 15 and $20 \mathrm{~g} / 1$ recorded 35.35, 
Table(9): Effect of potassium foliar application treatments on yield and fiber quality in Giza 94 variety in 2017 and 2018 seasons.

\begin{tabular}{|c|c|c|c|c|c|c|c|c|c|}
\hline \multirow{4}{*}{ Seasons (S) } & \multirow{4}{*}{$\begin{array}{c}\text { Potassium } \\
\text { Concentration } \\
\text { (C) }\end{array}$} & \multicolumn{8}{|c|}{ Yield and fiber quality } \\
\hline & & \multicolumn{3}{|c|}{ Yield data } & \multicolumn{5}{|c|}{ Fiber quality of HVI data } \\
\hline & & boll & & & & & & Uniform & \\
\hline & & $\begin{array}{c}\text { Weigh } \\
\text { t (g) }\end{array}$ & index & $\begin{array}{l}\text { percent } \\
\text {-age } \%\end{array}$ & reading & ty ratio & $\begin{array}{c}\text { Length } \\
(\mathrm{mm})\end{array}$ & $\begin{array}{c}\text { ity index } \\
\%\end{array}$ & $\begin{array}{c}\text { strength } \\
(\mathrm{g} / \mathrm{tex})\end{array}$ \\
\hline \multirow{5}{*}{2017} & 0 k (control) & 2.97 & 10.69 & 39.72 & 3.85 & 0.89 & 34.03 & 86.10 & 41.40 \\
\hline & $10 \mathrm{~g} / \mathrm{L}$ & 3.21 & 10.86 & 41.14 & 3.96 & 0.91 & 35.24 & 87.40 & 42.03 \\
\hline & $15 \mathrm{~g} / \mathrm{L}$ & 3.41 & 11.80 & 42.09 & 4.01 & 0.92 & 35.85 & 87.80 & 43.43 \\
\hline & $20 \mathrm{~g} / \mathrm{L}$ & 3.23 & 10.93 & 42.05 & 3.90 & 0.91 & 35.43 & 86.83 & 42.30 \\
\hline & MEAN & 3.21 & 11.07 & 41.25 & 3.88 & 0.91 & 35.14 & 87.03 & 42.29 \\
\hline \multirow{7}{*}{2018} & 0 k (control) & 3.17 & 10.79 & 40.50 & 3.82 & 0.88 & 34.00 & 84.93 & 41.57 \\
\hline & $10 \mathrm{~g} / \mathrm{L}$ & 3.34 & 11.26 & 41.54 & 3.98 & 0.91 & 35.45 & 87.20 & 42.50 \\
\hline & $15 \mathrm{~g} / \mathrm{L}$ & 3.47 & 12.20 & 42.49 & 4.11 & 0.94 & 35.98 & 88.03 & 43.10 \\
\hline & $20 \mathrm{~g} / \mathrm{L}$ & 3.33 & 11.33 & 41.50 & 3.99 & 0.91 & 35.63 & 87.37 & 42.57 \\
\hline & MEAN & 3.33 & 11.40 & 41.51 & 3.97 & 0.91 & 35.27 & 86.88 & 42.43 \\
\hline & 0 k (control) & 3.07 & 10.74 & 40.11 & 3.84 & 0.89 & 34.02 & 85.52 & 41.49 \\
\hline & $10 \mathrm{~g} / \mathrm{L}$ & 3.28 & 11.06 & 41.34 & 3.97 & 0.91 & 35.35 & 87.30 & 42.27 \\
\hline \multirow[t]{3}{*}{ Combined } & $15 \mathrm{~g} / \mathrm{L}$ & 3.44 & 12.00 & 42.29 & 4.06 & 0.93 & 35.92 & 87.92 & 43.27 \\
\hline & $20 \mathrm{~g} / \mathrm{L}$ & 3.28 & 11.13 & 41.78 & 3.85 & 0.91 & 35.53 & 87.10 & 42.44 \\
\hline & $\begin{array}{l}\text { General } \\
\text { mean }\end{array}$ & 3.27 & 11.24 & 41.38 & 3.93 & 0.91 & 35.21 & 86.96 & 42.36 \\
\hline \multirow{3}{*}{ LSD 0.5} & (S) & 0.08 & 0.19 & 0.61 & 0.19 & 0.01 & 0.62 & 0.94 & 0.99 \\
\hline & (C) & 0.12 & 0.27 & 0.86 & 0.26 & 0.02 & 0.88 & 1.2 & 1.41 \\
\hline & $(S * C)$ & 0.17 & 0.39 & 1.84 & 0.37 & 0.023 & 1.25 & 1.7 & 1.98 \\
\hline
\end{tabular}

Table (10): Effect of potassium foliar application treatments on yield and fiber quality in Giza 95 variety in 2017 and 2018 seasons.

\begin{tabular}{|c|c|c|c|c|c|c|c|c|c|}
\hline \multirow[b]{3}{*}{ Seasons (S) } & \multirow{3}{*}{$\begin{array}{c}\text { Potassium } \\
\text { Concentration } \\
\text { (C) }\end{array}$} & \multicolumn{8}{|c|}{ Yield and fiber quality } \\
\hline & & \multicolumn{3}{|c|}{ Yield data } & \multicolumn{5}{|c|}{ Fiber quality of HVI data } \\
\hline & & $\begin{array}{c}\text { Boll } \\
\text { Weight } \\
\text { (g) } \\
\end{array}$ & $\begin{array}{c}\text { Seed } \\
\text { index }\end{array}$ & $\begin{array}{c}\text { Lint } \\
\text { percentag } \\
\text { e } \% \\
\end{array}$ & $\begin{array}{c}\text { Micronai } \\
\text { re } \\
\text { reading } \\
\end{array}$ & $\begin{array}{l}\text { Maturity } \\
\text { ratio \% }\end{array}$ & $\begin{array}{c}\text { Fiber } \\
\text { length } \\
(\mathbf{m m}) \\
\end{array}$ & $\begin{array}{c}\text { Uniformi } \\
\text { ty index } \\
\% \\
\end{array}$ & $\begin{array}{c}\text { Fiber } \\
\text { strength } \\
\text { (g/tex) }\end{array}$ \\
\hline \multirow{5}{*}{2017} & 0 k (control) & 2.87 & 9.94 & 40.06 & 4.47 & 0.92 & 29.93 & 83.97 & 35.43 \\
\hline & $10 \mathrm{~g} / \mathrm{L}$ & 3.18 & 10.31 & 46.71 & 4.88 & 0.93 & 30.07 & 84.60 & 38.27 \\
\hline & $15 \mathrm{~g} / \mathrm{L}$ & 3.27 & 11.19 & 46.78 & 5.05 & 0.94 & 30.84 & 85.00 & 38.63 \\
\hline & $20 \mathrm{~g} / \mathrm{L}$ & 3.20 & $\mathbf{1 0 . 5 7}$ & 46.50 & 4.89 & 0.94 & 30.34 & 85.77 & 37.80 \\
\hline & MEAN & 3.13 & $\mathbf{1 0 . 5 0}$ & 45.01 & 4.82 & 0.94 & 30.30 & 84.83 & 37.53 \\
\hline \multirow{5}{*}{2018} & 0 k (control) & 3.10 & 10.16 & 40.70 & 4.58 & 0.93 & 29.83 & 84.03 & 35.13 \\
\hline & $10 \mathrm{~g} / \mathrm{L}$ & 3.21 & 10.35 & 46.83 & 4.88 & 0.94 & 30.42 & 85.00 & 37.93 \\
\hline & $15 \mathrm{~g} / \mathrm{L}$ & 3.40 & 11.24 & 46.90 & 5.14 & 0.95 & 31.52 & 85.33 & 38.70 \\
\hline & $20 \mathrm{~g} / \mathrm{L}$ & 3.25 & 10.48 & 46.64 & 4.88 & 0.94 & 30.3 & 84.93 & 38.07 \\
\hline & MEAN & 3.24 & 10.56 & 45.27 & 4.87 & 0.94 & 30.52 & 84.83 & 37.46 \\
\hline \multirow{5}{*}{ Combined } & 0 k (control) & 2.99 & 10.05 & 40.38 & 4.53 & 0.93 & 29.88 & 84.00 & 35.28 \\
\hline & $10 \mathrm{~g} / \mathrm{L}$ & 3.20 & 10.33 & 46.77 & 4.88 & 0.94 & 30.25 & 84.80 & 38.10 \\
\hline & $15 \mathrm{~g} / \mathrm{L}$ & 3.34 & 11.22 & 46.84 & 5.10 & 0.95 & 31.18 & 85.17 & 38.67 \\
\hline & $20 \mathrm{~g} / \mathrm{L}$ & 3.23 & 10.53 & 46.57 & 4.89 & 0.94 & 30.32 & 85.35 & 37.94 \\
\hline & General mean & 3.19 & 10.53 & 45.14 & 4.85 & 0.94 & 30.41 & 84.83 & 37.50 \\
\hline \multirow{3}{*}{ LSD 0.5} & (S) & 0.06 & 0.13 & 0.82 & 0.16 & 0.01 & 0.34 & 0.66 & 0.73 \\
\hline & (C) & 0.09 & 0.18 & 1.16 & 0.22 & 0.01 & 0.48 & 0.94 & 1.03 \\
\hline & $(\mathbf{S * C})$ & 0.13 & 0.25 & 1.64 & 0.32 & 0.02 & 0.67 & 1.33 & 1.45 \\
\hline
\end{tabular}

35.92 and $35.53 \mathrm{~mm}$ compared to $34.02 \mathrm{~mm}$ in the control. Giza 95 showed the same trend of Giza 94 to be $30.25,31.18$ and $30.32 \mathrm{~mm}$ compered to $29.88 \mathrm{~mm}$ in the control. Potassium foliar application improved slightly length uniformity index although of its statistical significance in both varieties along the two seasons. 
Potassium foliar application exhibited clear increase in fiber strength of the two varieties in the two seasons, being in Giza 94 (42.27, 43.27 and $42.44 \mathrm{~g} /$ tex) compared to $(41.49 \mathrm{~g} / \mathrm{tex})$ in the control and being in Giza 95 (38.10, 38.67 and $37.94 \mathrm{~g} /$ tex $)$ compared to $(35.28 \mathrm{~g} / \mathrm{tex})$ in the control. The differences in fiber strength between the three $\mathrm{K}$ treatments were not statistically significant. It is clear that potassium application treatment improved most of fiber quality traits. $15 \mathrm{~g} / \mathrm{l}$ of $\mathrm{K}$ proved to be the best $\mathrm{K}$ treatment regarding the studied fiber quality traits in both varieties. These results ensured that the foliar application of $\mathrm{K}$ is important during the fiber growth and development. Whereas, less supply of potassium can cause certain disorders such as decreasing fiber turgor pressure, resulting, low fiber elongation and shorter fibers. The obtained results confirmed by Aladakatti et al.(2011) Oosterthuis,(2002), Pettigrew, (2003) Shanmugham and Bhat (1991).

\section{Conclusion}

Potassium plays vital role in regulatory functions in biochemical and physiological processes that contribute to plant growth and boll development. Foliar application of $\mathrm{k}$ proved to have a great effect in improving and raise the productivity and fiber quality. This study indicated that $\mathrm{K}$ foliar application in the beginning and during flowering caused clear overlapping between fiber elongation and cellulose deposition (maturity). Furthermore, boll weight, seed index, lint $\%$ and most of fiber properties were improved by $\mathrm{K}$ foliar treatments.

The improvement in some yield and fiber quality traits, may be due to that enough supply of potassium during active fiber growth period may cause an increase in the turgor pressure of the fiber, resulting in higher cell elongation and longer fibers at maturity. Moreover, potassium plays a practically important role in fiber development and its shortage will result in poor fiber quality and lowered yield. $15 \mathrm{~g} / \mathrm{l}$ of $\mathrm{K}$ foliar application showed the longest and more mature fibers and the highest levels of the other fibers properties besides improving boll weight, lint and seed index.

\section{Acknowledgement}

The author would like to acknowledge Dr. Mounir Gad Sief Former Director of Cotton Research Institute, Research Professor of Cotton Technology for his great help and support during the conducting and preparation of this research and manuscript.

\section{REFERENCES}

ASTM D5867-05. (2005). Standard test method of measurement of physical properties of cotton fibers by High Volume Instruments. Annual Book of ASTM Standeds. 7: 02 section 7.

Abaye A.O. (1996). Potassium fertilization of cotton.Virgina Cooperative extension, Virginia State Univ.,USA, 1-8.

Afnan A., Hussin N. and Athar M. (2015). Role of potassium fertilizers in plant growth, crop yield and quality fiber production of cotton - An overview. Fuuast J. Biol., 5 (1): 27-35.

Aladakatti Y.A., Hallikeri S.S., Nandagavi R.A., Naveen N.E., Hugar A.Y. and Blaise D. (2011). Yield and fiber qualities of hybrid cotton (Gossypium hirsutum) as influenced by soil and foliar application of potassium. Karnataka J. Agric. Sci,. 24 (2): 133-136.

Ali A.K. and Armin M (2016). Influence of potassium foliar application on cotton yield (Gossypium barbadense L.) under saline condition.J. Crop Nutri. Sci. 2 (1): 52-60.

Andrew G.J. (2001). Cotton physiology today. National Cotton Council, Washinton, USA.12 (1):

Cakmak I., Hengeler C., Marschner H. (1994). Partitioning of shoot and root dry matter and carbohydrates in bean plants suffering from phosphorus, potassium and magnesium deficiency. J. Exp. Bot. 45, $1245-1250$.

Chen B., Chai Z., Shenc J., Zhang W. and Jiang P. (2017). Effect of potassium fertilizer on the physiological mechanisms of cotton fiber quality. Pak. J. Bot., 49 (3): 935-943.

Dewdar, M.D.H. (2013). Return of soil and foliar applications of potassium fertilization on potential and fiber quality traits for two (Gossypium barbadanse L.) varieties in Egypt, Scholarly J. Agric. Sci., (3): 94-98.

Dewdar M.D.H and Rady M.M. (2013). Influence of soil and foliar applications of potassium fertilization on growth, yield and fiber quality traits in two (Gossypium barbadanse L.) varieties. Afr. J. of Agric. Res. 8 (19) : 2211-2215.

Donald D.H. and Owen C.G. (1998). Foliar feeding cotton: Evaluating potassium 
sources, potassium soulation buffering and boron. Agron. J., 90:740-746.

Eiaz A.W., Ahmad R., Raja G.M.Hur., Ehsanullah, Ahmad A. and Nasir M. (2011). Response of foliar application of $\mathrm{KNO}_{3}$ on yield, yield components and lint quality of cotton (Gossypium hirsutum L.). Afri. J. Agric. Res., 6 (24): 5457-5463.

Howard D.D., Essington M.E., Gwathmey C.O. and Percell W.M. (2000). 'Buffering of foliar potassium and Boron solutions for no tillage cotton production', J. Cotton Sci., 4: 237- 244.

Lord E. (1981). The Origin and assessment of cotton fiber maturity. Tech. Res. Div., Int 'l. Ins. for Cotton, Manchester, UK.

Muhammad D.B., Afzal M.N, Tariq M. and Wakeel A. (2016). Impact of potassium fertilization dose, regime, and application methods on cotton development and seed cotton yield under arid environment. Electronic Int 1 . Fertiliz Correspondent (e-ifc), 45: 3-10

Muhammad T., Muhammad D.B., Afzal M.N., Ahmad M. and Wakeel A. (2017). Potassium use efficiency of cotton as affected by application method. Front. Potass. Sci. Conf., 25-27 J., Rome, Italy, 195-200.

Oosterhuis D.M. (2002). Potassium mangment of cotton. In :Potassium for Suslainable Crop Production. Pasricha, N.S. and Bansal, S.K. (Eds.) Int'l. Potash Inst. Basel. Switzerland. : 331346.

Pettigrew W.T. (2003). Relationship between insufficient potassium and crop maturity in cotton. Agron. J. 95: 1323-1329.

Pettigrew W.T. (2008). Potassium influences on yield and quality production for maize, wheat, soybean and cotton. Physiol. Plant., 133(4): 670-681.

Pettigrew W.T., McCarty J.C., Vaughn K.C. (2000). Leaf senescence-like characteristics contribut to cottons premature photosynthetic decline. Photosyn. Res.. 65: 187-195.

Rajendran K., Amanullah M.M. and Vaiyapuri K. (2010). Foliar nutrition in cotton- A review. Agric. Rev., 31(2): 120-126.

Ruan Y.L., Llewellyn D.J. and Furbank R.T. (2001). The control of single-celled cotton fiber elongation by developmentally reversible gating of plasmodomate and coordinated expression of sucrose and $\mathrm{K}+$ transporters and expansin. Plant Cell, 13: 47-60.

Sief M. G., Rokaia M. H. and Hanan M. A. (2016). Effect of cotton fiber maturity on its fineness measurements. Egypt. J. Appl. Sci, 31 (10): 240-255

Shanmugham K. and Bhat J.G. (1991). The effect of potassium on the fiber properties of high quality cotton varieties. J. Indian Soc. Cotton Improv., 16 (1):; 31-35.

Snedecor G.W and Cochran W.G. (1986). Statistical Method $7^{\text {th }}$ Edition Iowa. State Univ., Press, Ames, Iowa, USA.

Weir B.L. (1998). Foliar potassium bumps cotton yield. Research Reports. University of California Cooperative Extension, Davis, USA.

Xi S., Lihua R., Yongsong Z., Qizhoo T. and Lianxiang Q. (1989). Effect of potassium fertilizer application on physiological parameters and yield of cotton grown on a potassium deficient soil. Z. Pflanzenenerndhr. Bodenk, 152 (3) : 269272.

Younis Shimaa A. Sh. (2010). Fiber Fineness and maturity and their relation to other technological properties in Egyptian cotton. M. sc. Thesis, Fac. Agric. Ain Shams Univ., Egypt.

Zahoor A., Anjum S., Iqbal M.A and Rehman H.S. (2017). Foliar applied potassium enhances fiber quality, water relations and yield of cotton, J. Agric. Res. 56 (1): 1725

Zahoor A., Anjum S., Waraich E.A., Ayub M.A., Ahmad T., Tariq R.M.S.,Ahmad R. and Iqbal M.A. (2018). Growth, physiology and biochemical activities of plant responses with foliar potassium application under drought stress- a review. J. Plant Nutr., 41(1): 1- 10.

Zhao D., Oosterhuis D.M. and Bednarz C.W. (2001). Influence of potassium deficiency on photosynthesis, chlorophy II content, and chloroplast ultrastructure of cotton plants. Photosynthetica, 39(1): 103-109. 


\author{
تآثير البوتاسيوم علي نمو وتطور الألياف في القطن المصري \\ شيماء عبل ربه شحات \\ قسم بحوث الفسيولوجي- معهد بحوث القطن - مركز البحوث الزراعية ـالجيزة - مصر
}

أجريت تجربه لدراسه تاثثير الرش الورقي للبوتاسيوم علي مراحل نمو وتطور الألياف من حيث ميث معدل

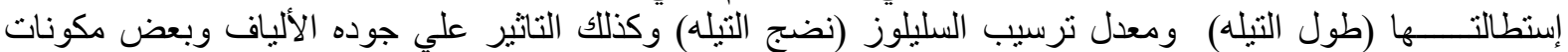

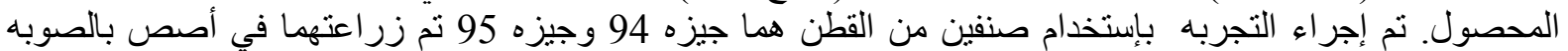

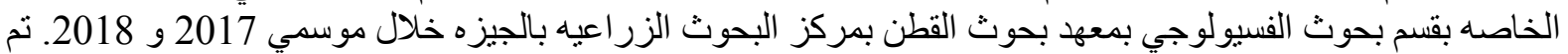

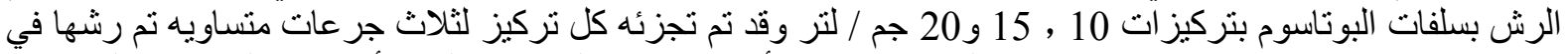

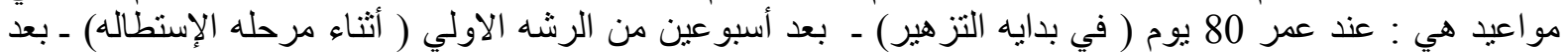

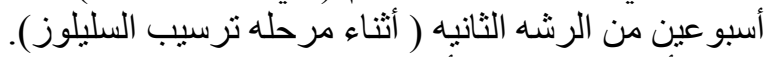

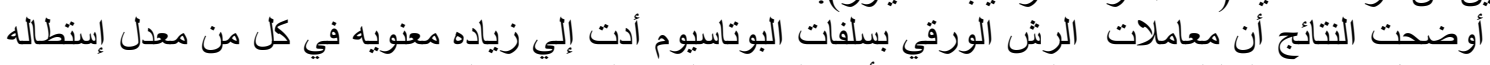

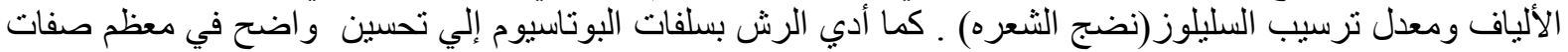

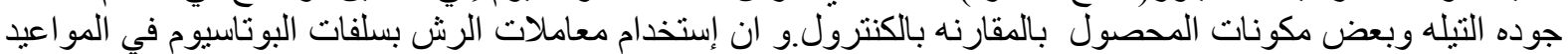

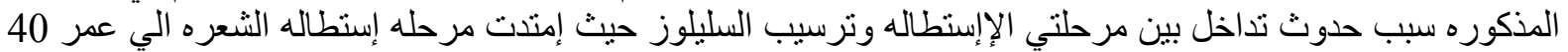

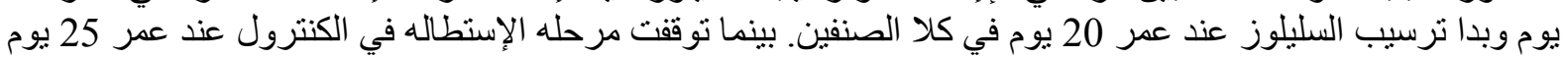
وبدات بعدها مرحله ترسيب السليلوز

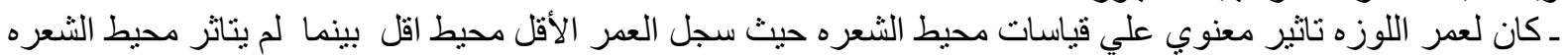

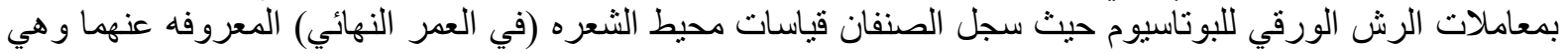

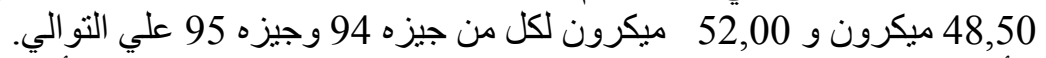

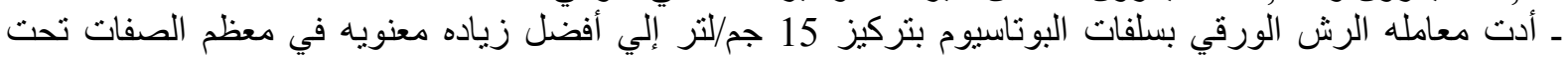
الدر اسه ويتضح ذلإنك من النتائج الآتبه: ـ فيما يتعلق بمعدل الإسنطاله سجلت المعامله 15 جم/لتر أطوال تبله مقدارها 10,20مد، 36,84مم و 37,79مم) عند

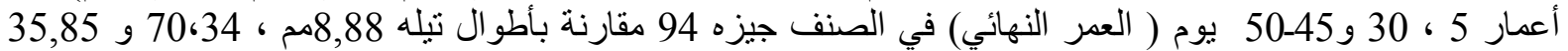
لنفس الأعمار علي التو الي في معامله الكنترول. وقد سلك الصنف فئف جيزه

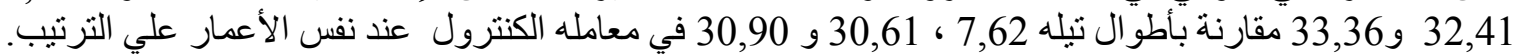

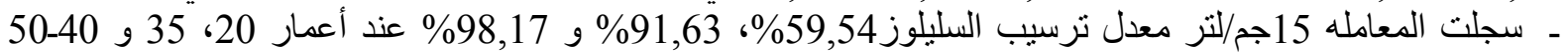

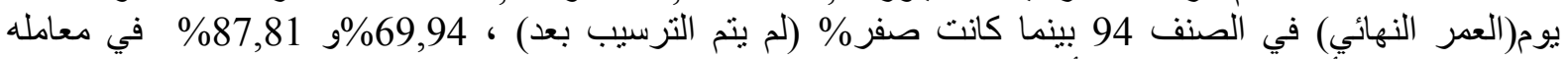

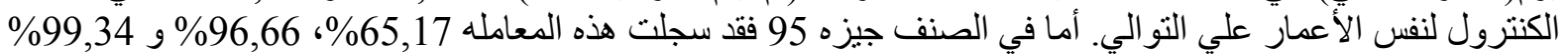

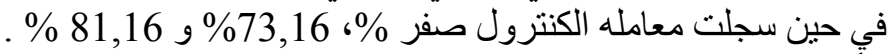

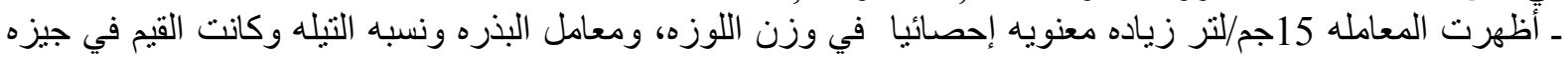

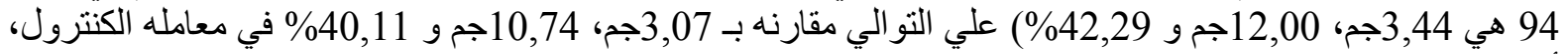

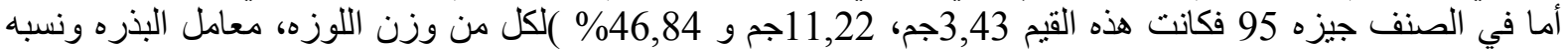

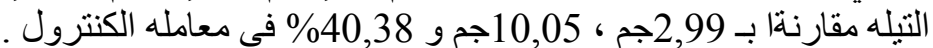

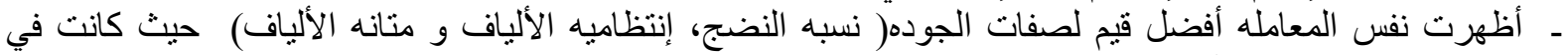

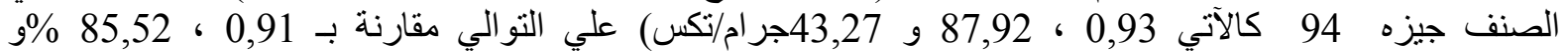

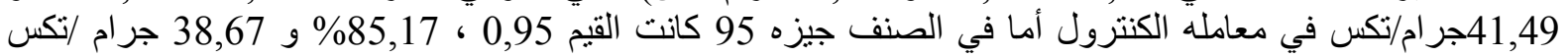

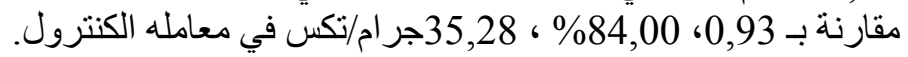

